\title{
PERSPECTIVES OF USING ORGANIZATIONAL AND PEDAGOGICAL EXPERIENCE OF THE FEDERAL REPUBLIC OF GERMANY IN THEOLOGICAL HIGHER EDUCATION INSTITUTIONS
}

\section{Yurii Taraban}

\section{INTRODUCTION}

The process of European integration of Ukraine has been started since 2005. Nowadays our country is consistently and systematically moving in the chosen direction along with actual challenges. Cooperation in the field of higher education is one of the major directions of cooperation between Ukraine and European Union in humanitarian direction ${ }^{1,2}$. The amount and quality of joint scientific and educational activities, attended by European and Ukrainian representatives of education and science, indicate that such cooperation is significant and has the perspective of development. The attention of contemporary Ukrainian and foreign scientists, who study the processes of globalization and integration and also theological and religious education, say about the importance of studying contemporary communications in religious-pedagogical environment. The essence of theoretic-pedagogical consolidation issues of theological education potential on the stage of the integration from Ukrainian into the European educational space involves not only education, but also Religion Studies, philosophy of culture, history of philosophy and sociology of religion. The importance of above-mentioned issues for Ukraine is caused by reactivation of the institutions of theological education in our country after a long period of atheism policy, and also by Eurointegration and globalization of processes during the Independence time.

\section{Factors affecting quality of the educational-organizational processes in training and theological education in Germany}

The theological education is a direction of pedagogics, that is mainly implemented into the communicative tasks. And due to the level of its

\footnotetext{
${ }^{1}$ Englert, R. (2002). Ziele religionspädagogischen Handels. In Bitter G., Englert R., Miller G., Nipkow K. E. Neues, Handbuch religionspädagogischer Grundbegriffe, (ss. 53-58). München: Kösel Verlag.

2 Terentiev, D. A. (2012). Factors of formation personal identity: the problem areas. Retrieved from: https://studylib.ru/doc/2638143/faktory-stanovleniya-lichnostnoj-identichnosti.
} 
success we can assume it regarding the progress of the theological educational system itself.

Theological education at a state university is one of the "common causes" (Rex mixt) of the state and the church manifestations, thus, documentation of each of the parties act together in order to achieve a common goal.

The churches of Germany have regard to the point that theological education can only coexist with the church. There is no undenominational theological education in Germany. Universities which are state secular institutions of higher education, are conformed by the norm regarding theological education (regardless of the organizational form and methods of providing education).

The results of a comprehensive study of theological and religious education in the German institutions of higher education are reflected in the following publications ${ }^{3,4,5,6,7}$.

The specificity of religious and theological educational activities could be determined as:

- usually educational projects are initiated and take part within one religious denomination. Scientific conferences, symposiums, seminars and other similar activities intend participation of individuals, who have general point of view and religious identity; are not confrontational or mutually exclusive in a fundamental point. Most commonly the discussions are revolved around the problems, which have common interest for participants. Positions and argumentation of debating sides stays within common religious identity;

- usually, the systematic theological education could be get in the institutions of corresponding religious confession. The main goal is to meet the learning needs of highly qualified specialists, who will gain the occupation in religious structures, secular institutions and also become scientists. Some educational projects have mono-religious ground; however, they can have intercultural and foreign-language basis. For example, the

${ }^{3}$ Hermisson, S., Rothgangel, M. (2016). Theologische Ausbildung und Spiritualität. Göttingen: Vienna University Press bei V \& Runipress.

${ }^{4}$ Katholische Theologie und Kirchliches Hochschulrecht. Einführung und Dokumentation der kirchlichen Rechtsnormen (2011) / hrsg. vom Sekretariat der Deutschen Bischofskonferenz. 2., vollst. überarb. Aufl. Bonn.

${ }^{5}$ Könemann, J., Sajak, C., Lechner, P. (2016). Einflussfaktoren religiöser Bildung. Eine qualitativ-explorative Studie. Simone: Springer, Wiesbaden.

${ }^{6}$ Lohrer, J. (2012). Call for Papers: Tagung - Religionslehrerbildung in der Krise? RPIvirtuel. 28.02. URL: http://info. blogs.rpi>virtuell.net/2012/02/28/call >for $>$ papers $>$ ta $>$ gung $>$ religionslehrerbildung $>$ in $>$ der $>$ krise.

${ }^{7}$ Ott, B. (2007) Handbuch Theologische Ausbildung - Grundlagen, Programmentwicklung, Leitungsfragen. R. Brockhaus Verlag, Wuppertal. 
corresponding religious confession of separate countries send their students to other countries for obtaining education. And after the graduation they come back;

- as a rule, interdenominational activities are based on corresponding documents and definitions, which were made by certain denomination by such contacts. Usually the boundaries of a discussion can be defined earlier to save a religious identity of parties in the discussion;

- the theological education for representatives of other denomination can be obtained in corresponding religion (christian religion, islam, etc.). We agree with the opinion of German experts J. Könemann, C. Sajak, S. Lechner ${ }^{8}$ that the theologist has to be a keeper of a worldview position as well, which is a ground for his own beliefs. Professional competences of theologist intend personal conviction to the essence of knowledge and skills, which are its content. At the same time, there is another point of view. The professor of pedagogics of Bonn university V. Ladenthin ${ }^{9}$ believes that education should not form mono-values, but show the existence of pluralism of cultures and diversity of axiological dimensions; it also should help the student to form his or her own opinion.

Certain experts in religious pedagogy believe that there is a crisis in the training of teachers in religious studies and the need to reform the concepts of teaching religious studies at schools ${ }^{10}$. Professor R. Englert believes that the subject matter of religious studies at school is a certain mode of the world cognition and the religious competence development ${ }^{11}$.

The researcher D. Terentiev analyzed some scientific works dedicated to the problem of self-identity, which let him to make such conclusions: a selfidentity is a complex structure, which includes representation of the person about himself and the world around, about the system of internal norms and values. The self-identified individual differs from other people, ensures integrity and originality, creates the ground for building relationships with representatives from communities with different characteristics ${ }^{12}$. According to the above-mentioned researches we can define such forms of

\footnotetext{
${ }^{8}$ Könemann, J., Sajak, C., Lechner, P. (2016). Einflussfaktoren religiöser Bildung. Eine qualitativ-explorative Studie. Simone: Springer, Wiesbaden.

${ }^{9}$ Ladenthin, V. (2015) Wozu religiöse Bildung heute? Sieben Versuche, an der Endlichkeit zu zweifeln. Würzburg.

${ }^{10}$ Ladenthin, V., Rekus, J. (2008). Werterziehung als Qualitätsdimension von Schule und Unterricht. Münster.

${ }^{11}$ Englert, R. (2002). Ziele religionspädagogischen Handels. In Bitter G., Englert R., Miller G., Nipkow K. E. Neues, Handbuch religionspädagogischer Grundbegriffe, (ss. 53-58). München: Kösel Verlag.

${ }^{12}$ Terentiev, D. A. (2012). Factors of formation personal identity: the problem areas. Retrieved from: https://studylib.ru/doc/2638143/faktory-stanovleniya-lichnostnoj-identichnosti.
} 
contemporary cooperation that characterize cooperation in the field of theological education:

- intercultural;

- interdenominational;

- interlingual.

Intercultural interaction is a consequence of identification of subjects of communication within one or more cultures or subcultures, which is considered by a person as his own and with which this person identifies himself and has the inner connection. Intercultural communication is communication of the worldview stereotypes, it is the critical perception of the worldview positions, different from its own, adoption of these positions (or their elements or modifications) for successful completion of the assignments.

Interdenominational cooperation is formed in the space which goes beyond the confession of one's own religion and building one's life in accordance with its postulate in the environment of fellow believers and like-minded people. Interdenominational cooperation could be:

1) exposition of self-identifying religious beliefs for others who are not fellow believers and have their own mindset and religious beliefs, which are part of the self-identification and the system of values;

2) participation in development of public positions beyond the religious doctrine that takes into consideration the worldview of different denominations and are aimed at social consolidation;

3) contraposition of one's own religious beliefs with others in confrontation, asserting one's right to one's own religious outlook, and building one's own life according to them.

Interlingual communication in the field of theological education goes beyond adequate fluency in the subjects of spoken and written language communicative interaction. Language plays the role of the principal communicator through which subjects can make available to others the content and meaning of the information reflecting beliefs, values, traditions, life principles and their embodiment in specific forms of religion, constructing life according to moral principles of faith. So, the degree of success in the cooperation projects in the field of theological education depends on the degree of success of implementation of intercultural, interdenominational and interlingual communication, reflecting the worldview and beliefs of the subjects of its participants.

\section{Obstacles, which appear in the process of communication and intercultural cooperation between the subjects of educational process}

The specificity of theological education as a field of activity and cooperation defines the specificity of the obstacles and problems on this way and also special methods of its constructive overcoming. That is why studies 
that cover above-mentioned field as a whole and determine some of its features are very important. To the factors that create obstacles to interaction in the field of theological education, could be included the following ones.

Interdenominational - come from the position of one or another religious creed of one's identity and ways of communicating with representatives of other religious identities; depend on how they are defined in the borders of their own confession.

The events in the field of interdenominational cooperation (conferences, seminars, congresses etc.), on which certain aspects of activity of the representatives of different faiths to achieve common goals are discussed, are valuable to all the participants in such cooperation as a rule. The participants of the above-mentioned events, leading by their own faith, which could differ depending on denomination, can achieve the goals during this cooperation only if there is a social-cultural space for its realization.

But at the same time, recognition of representatives of another religious community as an equal could be a big obstacle, since most of them are seen as violators of religious norms (the problem of schism, which arose as a result of cultural and historical background or political processes).

Belonging to different faiths is a significant obstacle not only for coeducation, but also for organizing joint co-educational events if participants explain the actions of other participants as a violation of their own standards of religious creed. That is why preparation for such events requires detailed agreement of the conceptual foundations of cooperation, ways and means of cooperative activities that did not cross the main positions of other participants.

Intercultural (mental) obstacles are the results of the differences in perception, assessment and practical application of knowledge and skills, which are the content and the result of theological education. The particular importance indicated obstacles appear, when students from different countries, who come from different ethnic, cultural, historical and linguistic communities, but at the same time relate to one denomination, enter the higher education institution. The experience of German higher education institutions, where representatives from many countries study theology, who belong to European identity, is an example of successful overcoming of mental intercultural obstacles.

Lingual obstacles barriers are technological: language proficiency sufficient for studying is a mandatory condition for those, who plan enter the theological faculty of German higher education institutions. Language proficiency is not only an understanding of educational material, which student perceives at lectures and seminars and during processing of scientific literature in the library. Language acquisition means learning the ways of thinking, stereotypes and features of constructing logic, scientific reasoning, justifications and conclusions that collectively form the academic culture. 
Along with scientific and methodological competence, language proficiency forms the scientific way of thinking and creates the conditions for gaining the high professional level.

Students-theologists, who study in German higher education institutions should have proficiency in classical languages (lingua Latina, ancient Greek) and should be ready to perform academic tasks, which involve fluency in these languages. Individuals, who have no proficiency in these languages have an opportunity to attend special language courses, but in their free time (during vacations).

Language proficiency, beyond mere communicative function in the studying process of theological students, helps to form the way of thinking, academic culture, mastering the ways of scientific work and spread the knowledge, which is a way to overcome the communication obstacles.

Technological and methodological obstacles are associated with an insufficient level of knowledge of information technologies and techniques that form the basis of the educational process at the theological faculty. Students who do not possess properly specified abilities and skills are deprived of the opportunity of full access to the entire spectrum of educational and methodological support of the educational process. The particular importance for the student has mastering of the technique of homework (Hausarbeiten). At the theological universities of Germany there is a special course, which gives an opportunity to get the competences in accomplishment of individual tasks under the guidance of the professor. Such skills form the ability not only for independent accomplishment of academic tasks, but for the critical thinking, the ability to think logically and consistently, accomplish scientific tasks. Combined with technology skills, these skills provide students with job opportunities.

Thus, cooperation in the field of theology education has revealed a number of problems that become an obstacle to perception, constructive borrowing and sharing of the potential of practical achievements. Overcoming these obstacles, in our opinion, is an important factor not only for cooperation, but also in the Ukrainian educational community for the space of European education and in the field of theology in particular.

Thus, we believe that overcoming the obstacles to understanding and perceiving the experience of theological education of Germany by Ukrainian higher education institutions is the direct consequence of the formulated lines of activity and problems of the domestic theological education that require constructive changes, as well as axiological significance of the experience in a holistic form or its elements. 


\section{The ways to overcome organizational and pedagogical problems in the field of theology at universities in Germany}

In order to adopt German practical experience in the field of theological education, Ukraine has to overcome the obstacles in the field of borrowing and practical application of the experience. First of all, the value and significance of the existing practical experience plays a decisive role in determining whether it is an object of borrowing, constructive adoption or not. The indicated aspect is a subjective parameter determining further direction of effective efforts for internalization. At the same time, the result will depend on whether mental obstacles (especially value-related ones) are overcome, whether the existing experience has sufficient value to create a need for borrowing. For Ukraine, the basis of this overcoming, in our opinion, is the processes of European integration and formation of a European identity, which includes a system of religious values (primarily Christian) as an integral component. Generally, coordination of the national education system and theological education in particular objectively creates conditions for the potential perception of the experience of theological education in Germany as valuable, constructive, such as to help solve the strategic problem including higher education institutions of Ukraine in the European educational space.

We believe that experience of the theological faculties of German universities can be used for creative borrowing (whole or partial) when solving issues in the field of domestic theological education.

It is worth to mention that borrowing the experience of the theological faculties of German universities is possible after the constructive solution to the following problems:

- definition of directions of activity and problems of domestic theological education, which has to be reformed;

- axiological significance of experience in a holistic form or its elements for embodiment in the field of theology;

- overcoming the obstacles to understanding and perception of the experience, caused by multiculturalism of the participants of cooperation process.

Having familiarized ourselves with the topics of scientific conferences held by religious institutions of theological education and universities over the past ten years in Ukraine, we can conclude that the issue of organizational and methodological support of the educational process was considered either in a historical aspect or fluently in the context of theological character. Specialists in the field of pedagogy were very rarely involved in such discussions and studies. Therefore, we can assume that Ukraine has not formulated a whole request for a search for ways and solutions to problems in the field of theological education. Indirectly, this is evidenced by the quality of normative and legislative support for theological 
education: the laws of Ukraine describe only in general terms the field of theological education, leaving most of the issues to the discretion of education institutions.

We are convinced that in Ukraine it is necessary to build a strategy for theological education and legislative support for its constructive implementation in the practical activities of theological faculties and faithbased education institutions. We believe that this strategy should include the following elements:

1. A comprehensive model of the modern religious society of Ukraine.

2. The structure of state education institutions engaged in educational activities of the theological field.

3. The structure of confessional and private education institutions involved in training of specialists in the field of theology.

4. The system of legal support for educational activities in education institutions of Ukraine (agreed with canonical and other religious and normative settings of the respective denominations).

5. Functional constructive system of interaction between the state and education institutions providing training in theology.

6. The system of training specialists of state structures competent in matters of religious life and theological education.

Each of these elements is a line of activity that needs to be specified. The axiological significance of the experience of the theological faculties of universities in Germany in many respects depends on such factors:

- place and role of theological faculties in the country's higher education system;

- prestige of profession and personnel popularity of specialists with higher theological education;

- level of opportunities for real employment of specialists who received a diploma of higher theological education;

- potential of academic mobility and the possibility of continuing studies or research work in another country.

The value of theological education in many respects depends on religious affiliation and the role of the corresponding denomination in society. For example, a theological education within the framework of a religious tradition historically inherent in a given society will have an advantage over religious trends that are not in the context of the cultural-historical tradition in this society. The axiological significance of theological education in many respects is an element of self-identification and civilization of applicants, as well as a reflection of the role and place of religion in society. At the same time, getting education within a religion that does not reproduce its "own" religious identity can significantly reduce the importance of the provided education, create obstacles and difficulties for applicants of a subjective 
nature, and also lay the foundation for the person to change the place of employment and the cultural environment of further residence.

It is traditionally believed that an effective way to overcome mental obstacles is to join the world academic culture through participation in scientific and cultural events of various levels and directions, which are carried out by higher education institutions of European countries.

Overcoming inter-confessional obstacles, in our opinion, is an important component for successful cooperation in the field of theological education and creation of conditions for development of cooperation in the educational sphere. We believe that for different denominations it may be promising to develop within each of them such norms and rules in the field of education that could be used by persons belonging to a particular religious tradition. At the same time, the state, as a guarantor of the success of inter-confessional relations, creates legal and functional opportunities for cooperation of representatives of various religious traditions in the educational sphere.

Disclaiming to solve all the existing contradictions and problems, this approach is able to create conditions for the needs of the religious part of society in the field of education in general and theological education in particular to be satisfied. In addition, within the framework of the mentioned approach, it is possible to describe new forms of religiosity and communications, including interdenominational ones.

Thus, organization of the educational process, implementation of teaching methods, as well as independent work of students, which makes up a significant part of the total amount of academic activity, a certain lifestyle of the theological faculty, a combination of knowledge and their application in the practice of religious life, social and church service - these are the components of successful overcoming the obstacles and mastering certain academic stereotypes that are the result of the activities of the theological faculty of the higher education institutions. Moreover, the experience of the theological faculties of universities in Germany can be considered as an example of a successful solution to these problems.

So, the success of implementation of cooperation projects in the field of theological education, in our opinion, is proportionally dependent on the degree of success of intercultural, interdenominational and interlingual interaction, reflecting the world outlook and faith of the subjects of its participants.

\section{Best practices for using the elements in the activities of the theological faculties of German higher education institutions to improve theologians training in Ukraine theological universities}

A study of the organizational and pedagogical activity of the theological faculties of the Federal Republic of Germany and how to use its elements in 
the practical activities of education institutions of Ukraine allows us to determine the following groups of recommendations:

- strategic;

- regulatory;

- normative and definitive;

- pedagogical;

- methodological;

- practical and technological;

- analytical;

- prognostic.

In our opinion, at the strategic level, the main goals in the field of theological education should be determined as a component of the modern educational space. We believe that any strategy in the field of theological education should take into account the influence of external and internal factors, objective and subjective influences, as well as the availability of appropriate resources and opportunities for realization of the goal.

The German experience is important in view of the fact that theological education strategy is a component of the state educational policy of this country, has a history of creation and functioning as an integral effective system. The model of cooperation between the Church and the state in Germany is unique and effective in modern socio-political and historical conditions, since it provides an effective solution to the pressing problems of the coexistence of these two social institutions. That is why the example of strategic planning of the Federal Republic of Germany in the field of education deserves investigation and can be applied by the Ukrainian higher education institutions.

The normative and definitive of recommendations provides for the use of ideas and principles, legal acts in accordance with which it is possible to build effective mechanisms for the functioning of the domestic theological education system. It should be noted that differences in the internal organization of the systems of Ukraine and Germany, the level of development of civil society, political, legal and academic culture, and other significant differences do not allow us to talk about copying or directly transferring the existing experience of Germany in Ukraine. But understanding of the legal and other regulatory principles and mechanisms, in the specific realities of the theological faculties of German universities that gave a positive result and ensured a high level of theological education, competitiveness and professional competence of graduates, can become the basis for changes in the legal support of theological education in Ukraine.

In our opinion, German experience is useful for Ukraine in the following areas:

1. Concordat system as a unique practice of church-state relations. 
2. The legal status of theological faculties in the higher education system in Germany.

3. Regulation of the financing system of theological faculties of Germany.

4. Providing social protection for professors and students of theological faculties.

The normative and definitive group of recommendations, similarly to the normative-legal one, cannot be interpreted as a direct copy of the experience of the German higher educational system, including theological one. The differences in the religious views of the population, history and traditions, the role and place of faiths in public life, the current state of religious communities in Ukraine and Germany are significantly different. But despite this, Germany has experience in building the relationships between denominations, differing in religious and spiritual-moral worldviews. That is why we believe that the idea and elements of the practical implementation of the coexistence of a variety of religious movements within a single institution of higher education can be useful in Ukraine.

In our opinion, special attention should be paid to such aspects of interdenominational relations in Germany:

1. Church-canonical support for the activities of theological faculties within concordats.

2. The place and role of religious centers and practice of building constructive working relations between them within the theological faculties.

3. The practice of attracting professors to teach special subjects at the theological faculties of German universities.

4. Religious and historical traditions and rules of the theological faculties of German universities that operate as a result of church canonical norms.

The pedagogical recommendations provide for borrowing the experience of the German Theological faculties in construction of mechanisms and borrowing ideas in the field of pedagogical management, in the direction of interdisciplinary relations via increasing competitiveness of specialists, they receive professional theological education in the labor market in church and secular society.

We believe that the following pedagogical experience of theological faculties of higher education institutions of Germany in the following areas deserve special attention:

1) motivation of applicants for admission to theological faculties;

2) practice of combining educational disciplines of a general scientific and special direction in a theological training course;

3) practice of combining theoretical and practical trainings at theological faculties; 
4) practice of socialization of theological students "free semester" and extracurricular forms of work;

5) further training and postgraduate internships in theology;

6) use of modern technologies and methods for accessing information sources in the research work of theologians.

The group of methodological recommendations is aimed at borrowing practical experience of organizing the educational process, as well as educational and methodological solutions to increase the effectiveness of training in the entire range of disciplines provided for students of theological faculties of German universities. The analysis of the methodological support of the educational process at theological faculties of Germany allows us to use the most successful solutions that increase the effectiveness of this activity while ensuring methodological support for:

1) study of individual academic disciplines of the theological cycle;

2) general educational, philosophical and cultural disciplines at theological faculties;

3) independent work of theological students;

4) preparation of theological students for seminars and exams;

5) practical training of theological students;

6) methodological recommendations on certain issues of the educational work of students of theological faculties, the use of the latest technologies and techniques.

The practical and technological recommendations are aimed at finding optimal practical solutions in the educational work, which include possession of equipment and technologies, methods of processing information, production of information products, use of information technologies and their individual elements.

We believe that it is important to focus our attention on such aspects of training students in theological departments of Germany:

1) acquisition of common competences in the field of latest technologies;

2) acquisition of skills of practical work with information sources;

3) acquisition of practical experience in producing an information product, which is the result of its own research work, resulting from the latest technology progress;

4) acquisition of communication skills in the modern virtual educational and scientific environment.

The analytical recommendations consist in further research of theological education institutions: their place and role in the country's higher education environment, internal and external factors of influence, the attitude to theological education institutions by various subjects of society (competition, partnership, opposition), results of activities of theological 
faculties (quantitative and qualitative indicators as the basis for further comprehensive analysis).

Our understanding is that recommendations for studying the experience of theological departments of Germany in the field of analytics can be formulated as following.

1. Creating a system of indicators and methods for constructing models that reproduce individual phenomena and processes of the educational and scientific activities of theological faculties, as well as complex models.

2. The determination of the criteria for a comprehensive analysis of the theological faculties.

3. Development of technologies for analytical research of the theological faculties in general and the individual elements and processes that are its components.

4. Recommendations on making amendments to the development strategy of theological education; legal, organizational and methodological support of the theological faculties.

The prognostic recommendations are aimed at creating theoretical models of the forecasted changes in the activities of theological departments to fulfill new tasks that have arisen in response to existing changes. Prognostic modeling is an important factor in adjusting the development strategy of theological education. The experience of forecasting and strategic planning of theological departments of Germany can be useful in this area of work.

We believe that Ukrainian system of theological education should focus on such aspects in forecasting:

1) changes in the religious structure of society, global and regional trends and processes, and consequences of changes in the religious sphere;

2) people's attitude to religion (religiosity, religious ethics and behavior);

3) contradictions and conflicts on religious grounds, which carry the potential for danger, including global;

4) functioning of religious educational centers, analysis of the activities of authoritative religious leaders and theologians, trends and directions of development of theological scientific thought;

5) phenomena and processes initiated by theological education institutions, theological faculties, authoritative theologians.

\section{CONCLUSIONS}

The results of the research allow us to draw the following conclusions:

1. The features of training theology specialists at the universities of the Federal Republic of Germany are highlighted and characterized. 
2. The conditions under which the experience of the theological faculties of Germany or its elements may be relevant for specialists in Ukraine are defined and characterized.

3. The obstacles for the perception the experience of theological faculties of Germany are identified.

4. The directions and methods of overcoming the indicated obstacles of the higher education institutions of the Federal Republic of Germany are characterized. In our opinion, existing experience can become the basis for borrowing individual elements in Ukraine.

5. For the first time, the classification of recommendations on borrowing the experience of theological faculties is presented, a characteristic of each level is given, and practical activities in each direction are formulated.

\section{SUMMARY}

The main features of training theology specialists at the universities of the Federal Republic of Germany are highlighted and characterized in the research. The conditions under which the experience of the theological faculties of Germany or its elements may be relevant for specialists in Ukraine are defined and characterized. Also, the obstacles for the perception of the experience of theological faculties of Germany are identified. The directions and methods of overcoming the indicated obstacles of the higher education institutions of the Federal Republic of Germany are characterized. In our opinion, the existing experience can become the basis for borrowing individual elements in Ukraine. For the first time, the classification of recommendations on borrowing the experience of theological faculties is presented, the characteristics of each level is given, and practical activities in each direction are formulated. A study of the organizational and pedagogical activities of the theological faculties of the Federal Republic of Germany helps to use their elements in the practical activities of education institutions of Ukraine and allows us to determine practical recommendations for the future.

\section{REFERENCES}

1. Eckpunkte für die Studienstruktur in Studiengängen mit Katholischer oder Evangelischer Theologie/Religion Beschluss der Kultusministerkonferenz vom 13.12.2007.

2. Englert, R. (2002). Ziele religionspädagogischen Handels. In Bitter G., Englert R., Miller G., Nipkow K. E. Neues, Handbuch religionspädagogischer Grundbegriffe, (ss. 53-58). München: Kösel Verlag.

3. Empfehlungen zur Weiterentwicklung von Theologien und religionsbezogenen Wissenschaften an deutschen Hochschulen (2010). Wissenschaftsrat Köln. 
4. Hermisson, S., Rothgangel, M. (2016). Theologische Ausbildung und Spiritualität. Göttingen: Vienna University Press bei V \& Runipress.

5. Katholische Theologie und Kirchliches Hochschulrecht. Einführung und Dokumentation der kirchlichen Rechtsnormen (2011) / hrsg. vom Sekretariat der Deutschen Bischofskonferenz. 2., vollst. überarb. Aufl. Bonn.

6. Könemann, J., Sajak, C., Lechner, P. (2016). Einflussfaktoren religiöser Bildung. Eine qualitativ-explorative Studie. Simone: Springer, Wiesbaden.

7. Ladenthin, V., Rekus, J. (2008). Werterziehung als Qualitätsdimension von Schule und Unterricht. Münster.

8. Ladenthin, V. (2015) Wozu religiöse Bildung heute? Sieben Versuche, an der Endlichkeit zu zweifeln. Würzburg.

9. Lohrer, J. (2012). Call for Papers: Tagung - Religionslehrerbildung in der Krise? RPIvirtuel. 28.02. URL: http://info. blogs.rpi > virtuell.net/2012/02/28/call>for > papers >ta $>$ gung $>$ religionslehrerb ildung $>$ in $>$ der $>$ krise.

10. Ott, B. (2007) Handbuch Theologische Ausbildung - Grundlagen, Programmentwicklung, Leitungsfragen. R. Brockhaus Verlag, Wuppertal.

11. Rötzer, A. (2003). Die Einteilung der Wissenschaften - Analyse und Typologisierung von Wissenschaftsklassifikationen.

12. Danylenko, L. I., Polishchuk, I. V. (2013). Perspectives and challenges of European integration processes for Ukraine: teaching method. materials. K.: NASM. Retrieved from: http://academy.gov.ua/ NMKD/library_nadu/Navch_Posybniky/b9495ad9-9223-471a-868546d10342551e.pdf.

13. Nesterovych, V. F. (2009). The role and place of lobbying in the European integration of Ukraine. Bulletin of the Ministry of Justice of Ukraine, 3, 32-42.

14. Rashyvalov, D. P. European Integration Strategy of Ukraine. In L. V. Huberskyi (Ed.), Ukrainian Diplomatic Encyclopedia: In 2 vols. Vol. 1. K.: Knowledge of Ukraine.

15. Terentiev, D. A. (2012). Factors of formation personal identity: the problem areas. Retrieved from: https://studylib.ru/doc/2638143/faktorystanovleniya-lichnostnoj-identichnosti.

\section{Information about the author:} Yurii Taraban,

Postgraduate Student

Sumy State Pedagogical University named after A. S. Makarenko,

87, Romenska str., 40002, Sumy, Ukraine ORCID ID: orcid.org/0000-0001-8895-3751 